\title{
Does anybody support the supporters? Social support in the cancer patient-caregiver dyad
}

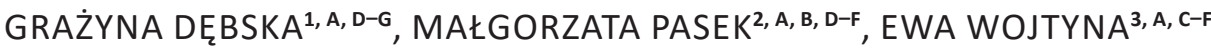

${ }^{1}$ Faculty of Health and Medical Sciences, Andrzej Frycz Modrzewski Cracow University, Poland

${ }^{2}$ Maria Sklodowska-Curie Institute - Oncology Center Cracow Branch, Poland

${ }^{3}$ Institute of Psychology, University of Silesia in Katowice, Poland

A - Study Design, B - Data Collection, C - Statistical Analysis, D - Data Interpretation, E - Manuscript Preparation, F - Literature Search, G - Funds Collection

Summary Background. Cancer and its treatment enforce changes in patient functioning. The principal objective of each patient is to efficiently cope with the disease, i.e. to completely recover or at least to slow its progression. Under such circumstances, patients and their relatives require various forms of support: emotional, informational and instrumental.

Objectives. The aim of the study was to determine the level and sources of support available for cancer patients and their close relatives, who deal with the latter on a daily basis.

Material and methods. The cross-sectional self-inventory study, conducted at cancer centers in Krakow and Tarnow, included 193 pairs of cancer patients and their caregivers. The study was based on the Berlin Social Support Scales and a sociodemographic-clinical survey. Results. Cancer patients had more perceived and received social support than their caregivers. Patients identified more sources of available support than their caregivers. When the level of support was stratified according to the caregiver's relation with the patient, caregivers-partners and caregivers-children presented higher levels of perceived support than caregivers-siblings and caregivers-parents. Caregivers received less support than patients from medical personnel.

Conclusions. The discrepancy between the level of social support among patient and their caregivers leads to further research on the patient-caregiver dyad, especially with regard to the consequences for the whole family's quality of life. In connection with a deficit of support for caregivers from oncologists, GP's may constitute a valuable source of support, especially emotional and informational. Key words: social support, cancer, patient, caregiver.

Dębska G, Pasek M, Wojtyna E. Does anybody support the supporters? Social support in the cancer patient-caregiver dyad. Fam Med Prim Care Rev 2017; 19(2): 110-113, doi: https://doi.org/10.5114/fmpcr.2017.67863.

\section{Background}

Cancer and its treatment enforce changes in the functioning of a patient. This is with no doubt a traumatic experience, also for close relatives of the patient. It disrupts their sense of safety, changes their expectations, systems of values and needs [1]. Under such circumstances, patients and their relatives require various forms of support: emotional, informational and instrumental. Emotional support, i.e. exchange of emotions, should reduce stress, thus providing the patient with a feeling of safety and hope. This can be expressed via verbal and non-verbal communication, e.g. "We love you" or "We are by your side" [2]. Instrumental support manifests as help in specific activities, and informational support as providing one with the information he/she needs to deal with a given problem. Importantly, this support should be adequate to the demands of its recipients and should allow them to develop constructive methods to cope with the disease [2]. Social support should be considered a health-oriented resource and, as such, should not be neglected during the treatment process, as it may constitute a vital determinant of biopsychosocial wellbeing [2-4].

Many previous studies have documented the beneficial effects of support on the quality of life of cancer patients $[1,3$, 4]. However, equally important, albeit often neglected or inadequately highlighted, is support for the supporters. In real life practice, caregivers are expected to constantly remain on duty and immediately respond to all patient needs. This places supporters at an increased risk of burnout $[5,6]$.
A review of published evidence regarding social support in oncology demonstrated that in Polish conditions, the available data on its levels and sources in a patient-caregiver dyad are limited. Therefore, the hereby-presented results of an empirical study may find application in the everyday practice of physicians/nurses who deal with complex relationships between cancer patients and their caregivers.

\section{Objectives}

The aim of the study was to determine the level and sources of support available for cancer patients and their caregivers.

\section{Material and methods}

The cross-sectional self-inventory study was conducted at the Center of Oncology, M. Sklodowska-Curie Memorial Institute in Cracow and at the St. Luke Provincial Hospital in Tarnow (Poland). The protocol of the study was granted approval by the Local Bioethics Committee of the Andrzej Frycz-Modrzewski Cracow University (Poland).

\section{Participants}

The study included 193 pairs of cancer patients and their caregivers. A caregiver was defined as an adult close relative identified by the patient, who stayed at his/her place and provided him/her with daily care. Only those patients who provid- 
ed their written informed consent to participate, who were diagnosed with cancer (between 3 and 12 months previously) and who were undergoing anticancer treatment at the time of the study were enrolled. Detailed characteristics of the participants are presented in Table 1.

\begin{tabular}{|c|c|c|c|c|}
\hline \multirow[t]{2}{*}{ Characteristics } & \multicolumn{2}{|c|}{ Patients } & \multicolumn{2}{|c|}{ Caregivers } \\
\hline & $n$ & $\%$ & $n$ & $\%$ \\
\hline $\begin{array}{l}\text { Sex } \\
\quad \text { Women } \\
\text { Men }\end{array}$ & $\begin{array}{l}108 \\
85 \\
\end{array}$ & $\begin{array}{l}56 \\
44 \\
\end{array}$ & $\begin{array}{l}133 \\
60\end{array}$ & $\begin{array}{l}68.9 \\
31.1\end{array}$ \\
\hline $\begin{array}{l}\text { Age } \\
\qquad \begin{array}{l}M(S D) \\
\text { Range }\end{array}\end{array}$ & \multicolumn{2}{|c|}{$\begin{array}{l}59.89(11.88) \\
27-84\end{array}$} & \multicolumn{2}{|c|}{$\begin{array}{l}49.92(15.09) \\
18-80\end{array}$} \\
\hline $\begin{array}{l}\text { Marital status } \\
\text { Single } \\
\text { Married } \\
\text { Widowed } \\
\end{array}$ & \begin{tabular}{|l}
8 \\
155 \\
30 \\
\end{tabular} & \begin{tabular}{|l|}
4.1 \\
80.3 \\
15.5 \\
\end{tabular} & $\begin{array}{l}32 \\
154 \\
7 \\
\end{array}$ & $\begin{array}{l}16.6 \\
79.8 \\
3.6 \\
\end{array}$ \\
\hline $\begin{array}{l}\text { Place of residence } \\
\text { Village } \\
\text { Town up to } 100,000 \\
\text { Town above } 100,000 \\
\end{array}$ & $\begin{array}{l}82 \\
44 \\
67 \\
\end{array}$ & \begin{tabular}{|l|}
42.5 \\
22.8 \\
34.7 \\
\end{tabular} & $\begin{array}{l}73 \\
49 \\
71 \\
\end{array}$ & $\begin{array}{l}37.8 \\
25.4 \\
36.8 \\
\end{array}$ \\
\hline $\begin{array}{l}\text { Relation with patient } \\
\text { Patient's partner } \\
\text { Patient's child } \\
\text { Patient's sibling } \\
\text { Patient's parent }\end{array}$ & & & $\begin{array}{l}91 \\
60 \\
22 \\
20\end{array}$ & $\begin{array}{l}47.2 \\
31.1 \\
11.4 \\
10.4\end{array}$ \\
\hline
\end{tabular}

\section{Instruments}

The study was based on the Berlin Social Support Scales (BSSS) and a sociodemographic-clinical survey. BSSS is an instrument consisting of a number of scales to determine various types of social support: Perceived Support (emotional - 4 items; instrumental -4 items) and Received Support (emotional - 9 items; instrumental - 3 items; informational -2 items; satisfaction with support - 1 item) [7]. Each item is scored on a 4-point Likert scale (from 1 - strongly disagree, to 4 - strongly agree). The higher the final score, the higher the level of support in a given dimension. Validity and reliability had been previously demonstrated [7], and reliability was acceptable in this study (Cronbach's $\alpha \geq 0.85$ ). BSSS has been used before in patients with cancer and their caregivers [8].

\section{Statistical analysis}

Statistical analysis was carried out with SPSS ver. 23 . The statistical significance of differences between the study groups was verified with the Student $t$-test and ANOVA (with LSD post-hoc test). The effect size was expressed with Cohen's $d$-coefficients [9]. Power and direction of associations within pairs of variables were determined on the basis of Kendall's tau- $b$ coefficients of linear correlation.

\section{Results}

Most patients participating in the study had received anticancer treatment for a few months: $1-3(34.7 \%)$ or $4-12$ (41.5\%). The remaining $28.8 \%$ of the study subjects had a 1 - to 2-year history of treatment.

Analysis of social support levels (Table 2) demonstrated slight differences (Cohen's $d<0.5$ ) between cancer patients and their caregivers. Patients received more support than their caregivers and were more satisfied with the support received. Patients and caregivers did not differ in the levels of perceived emotional support. However, the level of truly received support turned out to be higher in patients than in their caregivers, especially with regards to instrumental support. The level of all types of social support for cancer patients and their caregivers was not influenced by the time of cancer treatment $(p>0.05)$.

\begin{tabular}{|c|c|c|c|c|}
\hline \multirow[t]{2}{*}{ Scale } & \multirow[t]{2}{*}{ Patients } & \multirow[t]{2}{*}{ Caregivers } & \multicolumn{2}{|c|}{ Comparison } \\
\hline & & & $p$ & $\begin{array}{l}\text { Cohen's } \\
\text { d }\end{array}$ \\
\hline $\begin{array}{l}\text { Perceived Support } \\
\text { Emotional } \\
\text { Instrumental }\end{array}$ & $\begin{array}{l}29.95(3.75) \\
14.18(2.09) \\
14.87(2.06)\end{array}$ & $\begin{array}{l}28.15(4.36) \\
13.89(2.32) \\
14.26(2.34)\end{array}$ & $\begin{array}{l}.007 \\
.135 \\
.001\end{array}$ & .44 \\
\hline $\begin{array}{l}\text { Received Support } \\
\text { Emotional } \\
\text { Instrumental } \\
\text { Informational }\end{array}$ & $\begin{array}{l}51.72(6.02) \\
33.37(4.01) \\
11.26(1.37) \\
7.09(1.29)\end{array}$ & $\begin{array}{l}49.12(7.28) \\
31.80(4.72) \\
10.54(1.82) \\
6.78(1.46)\end{array}$ & $\begin{array}{l}<.001 \\
<.001 \\
<.001 \\
.006\end{array}$ & $\begin{array}{l}.39 \\
.34 \\
.47 \\
.23\end{array}$ \\
\hline Satisfaction & $3.83(0.48)$ & $3.62(0.68)$ & $<.001$ & .37 \\
\hline
\end{tabular}

$n=193$.

Furthermore, cancer patients identified more sources of available support than their caregivers $(t=7.27 ; p<0.001$; $d=0.59$ ). The mean number of support sources identified by patients approximated $3(M=2.94 ; S D=1.61$; range: $0-8)$. Typically, patients obtained support from their partners, medical personnel and children. In turn, caregivers obtained support from 2 sources on average $(M=2.09 ; S D=1.27$; range: $1-8)$, usually from their partners, children and siblings (Figure 1).

Patients, slightly more often than their caregivers, declared obtaining support from their partners. Furthermore, they point-

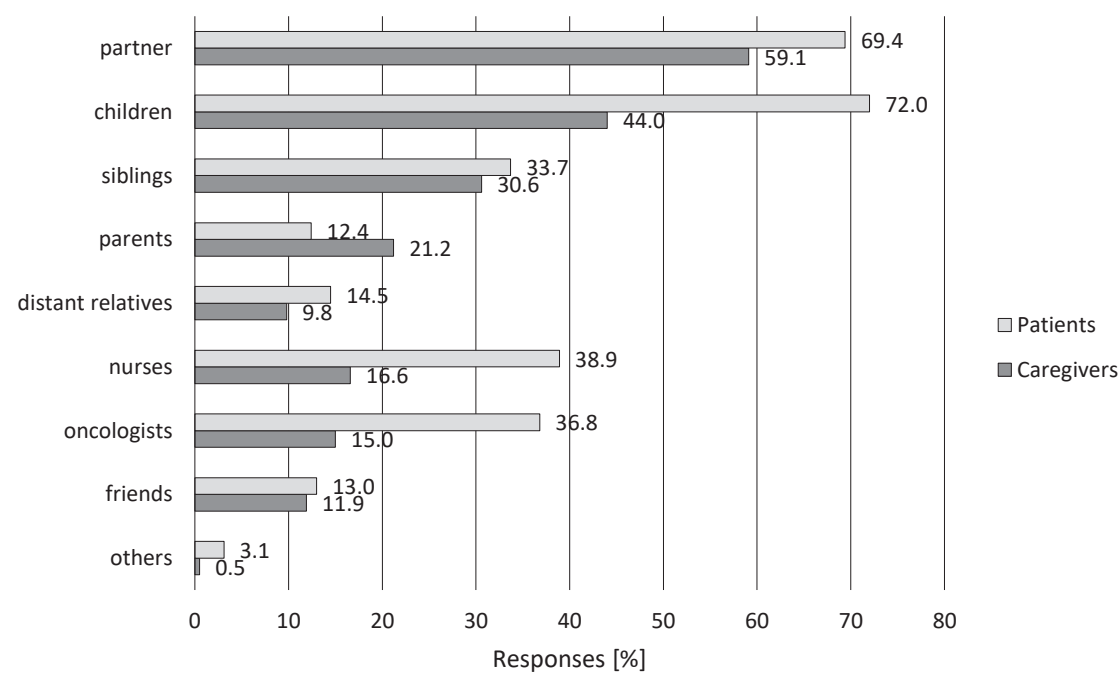

Figure 1. Support sources identified by patients and their caregivers 


\begin{tabular}{|c|c|c|c|c|c|c|c|}
\hline \multirow[b]{2}{*}{ Social support [M (SD)] } & \multicolumn{4}{|c|}{ Relation with patient } & \multicolumn{3}{|c|}{ ANOVA } \\
\hline & Pt & Ch & Si & $\operatorname{Pr}$ & $p$ & LSD & d \\
\hline Perceived support & $28.50(4.01)$ & $28.53(4.37)$ & $26.09(5.22)$ & $25.20(4.55)$ & .038 & $\begin{array}{l}\mathrm{Pt}>\mathrm{Si} \\
\mathrm{Pt}>\mathrm{Pr} \\
\mathrm{Ch}>\mathrm{Si} \\
\mathrm{Ch}>\mathrm{Pr}\end{array}$ & $\begin{array}{l}.52 \\
.77 \\
.51 \\
.75\end{array}$ \\
\hline Emotional & $14.00(2.18)$ & $14.11(2.39)$ & $12.95(2.52)$ & $12.80(2.59)$ & .035 & $\begin{array}{l}\mathrm{Pt}>\mathrm{Si} \\
\mathrm{Pt}>\mathrm{Pr} \\
\mathrm{Ch}>\mathrm{Si} \\
\mathrm{Ch}>\mathrm{Pr}\end{array}$ & $\begin{array}{l}.45 \\
.50 \\
.47 \\
.53\end{array}$ \\
\hline Instrumental & $14.50(2.02)$ & $14.41(2.32)$ & $13.14(3.06)$ & $12.40(3.29)$ & .021 & $\begin{array}{l}\mathrm{Pt}>\mathrm{Si} \\
\mathrm{Pt}>\mathrm{Pr} \\
\mathrm{Ch}>\mathrm{Si} \\
\mathrm{Ch}>\mathrm{Pr}\end{array}$ & $\begin{array}{l}.52 \\
.77 \\
.47 \\
.71 \\
\end{array}$ \\
\hline Received support & $50.31(6.15)$ & $48.51(7.66)$ & $45.82(9.70)$ & $49.20(6.61)$ & .045 & $\mathrm{Pt}>\mathrm{Si}$ & .55 \\
\hline Emotional & $32.43(4.07)$ & $31.53(5.00)$ & $29.82(6.18)$ & $32.20(3.63)$ & .049 & $\mathrm{Pt}>\mathrm{Si}$ & .50 \\
\hline Instrumental & $10.86(1.53)$ & $10.37(1.94)$ & $9.68(2.42)$ & $10.60(1.34)$ & .035 & $\mathrm{Pt}>\mathrm{Si}$ & .58 \\
\hline Informational & $7.02(1.28)$ & $6.61(1.49)$ & $6.32(1.86)$ & $6.40(1.82)$ & .047 & $\begin{array}{l}\mathrm{Pt}>\mathrm{Si} \\
\mathrm{Pt}>\mathrm{Pr}\end{array}$ & $\begin{array}{l}.44 \\
.39\end{array}$ \\
\hline Satisfaction & $3.68(0.59)$ & $3.66(0.63)$ & $3.32(0.99)$ & $3.40(0.89)$ & .049 & $\begin{array}{l}\mathrm{Pt}>\mathrm{Si} \\
\mathrm{Ch}>\mathrm{Si}\end{array}$ & $\begin{array}{l}.44 \\
.41\end{array}$ \\
\hline
\end{tabular}

$n=193$; Pt - patient's partner, Ch - patient's child, Si - patient's sibling, Pr - patient's parent; LSD - least significant differences post-hoc test; $d$-Cohen's $d$ coefficient (effect size).

ed to medical personnel, namely nurses and oncologists, as a source of support markedly more often than their caregivers.

When the level of support was stratified according to caregiver's relation with the patient, caregivers-partners and caregivers-children presented with higher levels of perceived emotional and instrumental support than caregivers-siblings and caregivers-parents (Table 3). The levels of truly received support also turned out to be higher in the case of caregivers-partners than in caregivers-siblings. Moreover, the level of informational support received by caregivers-partners was significantly higher than that obtained by caregivers-parents. Finally, both caregivers-partners and caregivers-children declared greater satisfaction with obtained support than caregivers-siblings.

\section{Discussion}

This study demonstrated that although cancer patients and their caregivers show similar demands for support, the latter receive less support and are less satisfied with the level and the type of actually obtained support. This is a deficit of instrumental support received by the caregivers, which seems to be crucial to understand this relationship. While emotional support may attenuate a caregiver's distress associated with the patient's status, it is still insufficient to overcome some challenges, such as the need for daily care, assistance during medical tests and procedures, administration of medications and provision of other everyday needs. These activities considerably add to the regular duties of caregivers and which are associated with their occupational activity and family life. Lack of specific support in fulfilling these additional duties may contribute to frustration, exhaustion and, eventually, even burnout $[1,2,10]$.

Cancer is perceived in the community as a particularly serious problem and which deserves special attention. As a result, both closer and distant relatives usually focus on the patient's needs, while the needs of their caregivers are typically neglected $[5,10]$. This was also confirmed in our present study, which demonstrated that while cancer patients may expect support from both their families and medical personnel, their caregivers rely solely on their closest relatives. Furthermore, with time, family members may become exhausted while supporting the patient, and they may put additional pressure on the principal caregiver. A strong conviction exists in Polish culture that the caregiver should completely devote himself/herself to the patient $[5,10]$. Consequently, manifestation of frustration and other negative emotions (e.g. anger) by the caregiver, or even his/her temporary isolation from the patient, will inevitably be condemned by others. The resultant fear of social disapproval may make caregivers reluctant to ask for help or to express their needs, which will eventually result in further deprivation of the support received.

Caregivers often need specific instructions from medical personnel. However, the latter usually offer their support to patients rather than to their caregivers. As a result, caregivers may feel abandoned in fulfilling their roles. It should be emphasized that support from individuals who can better understand a difficult situation (such as medical personnel) is usually more helpful than that offered by a third party.

Another interesting finding of our study is the fact that caregivers-partners and caregivers-children may expect more support than caregiver-siblings and caregivers-parents. Caregivers-partners and caregivers-children may be provided with emotional and instrumental support by their own children (in the case of caregivers-partners) or partners (in the case of caregivers-children) and have likely obtained some emotional support from their patients. Consequently, they received support from their close relatives, who know them well. The alignment of emotional needs in the patient-partner or patient-child dyad also plays an unquestioned role $[10,11]$. In turn, lower levels of support received by caregivers-siblings and caregivers-parents may at least in part result from the emotional involvement of their close relatives in the case of a neoplastic disease. This hypothesis is supported by the fact that caregivers from these two groups identified their partners (in the case of caregiversparents) or parents (in the case of caregivers-siblings) as the principal source of support; consequently, they both expected support from the patient's parents.

\section{Conclusions}

Caregivers receive less support than cancer patients, including from medical personnel, i.e. oncologists and nurses. This discrepancy between the level of social support among patients 
and their caregivers leads to further research on the patient-caregiver dyad, especially with regard to the consequences for the whole family's quality of life. In connection with a deficit of support for caregivers from oncologists, family physicians may constitute a valuable source of support, especially emotional and informational.

Source of funding: The study was supported through research and development funds from the Ministry of Science and Higher Education Poland within the framework of statutory activities (research task no. WZiNM/DS/3/2015-KON).

Conflict of interest: The authors declare no conflict of interests.

\section{References}

1. Holland J, Breitbart WS, Butow PN, et al., eds. Psycho-Oncology. 3rd ed. Oxford: Oxford University Press; 2015.

2. Cieślak R, Sęk H, eds. Wsparcie społeczne, stres i zdrowie. Warszawa: Wydawnictwo Naukowe PWN; 2006.

3. Høyer M, Johansson B, Nordin K, et al. Health-related quality of life among women with breast cancer - a population-based study. Acta Oncol 2011; 50: 1015-1026.

4. Epplein M, Zheng Y, Zheng W, et al. Quality of life after breast cancer diagnosis and survival. J Clin Oncol 2011; 29: 404-412.

5. Wirga M, Wojtyna E. Udręki zdrowego umysłu. Neuropsychologia cierpienia. In: Binnebesel J, Błeszyński J, Domżał Z, eds. Wielowymiarowość cierpienia. Łódź: Wydawnictwo Naukowe WSEZ; 2010: 31-51 (in Polish).

6. Gawlik M, Kurpas D. Ocena poziomu wypalenia członków rodzin w opiece nad pacjentem z chorobą nowotworową objętych domową opieką paliatywną. Fam Med Prim Care Rev 2014; 16(4): 336-340 (in Polish).

7. Łuszczyńska A, Mazurkiewicz M, Kowalska M, et al. Berlińskie Skale Wsparcia Społecznego (BSSS): wyniki wstępnych badań nad adaptacją skal i ich własnościami psychometrycznymi. Studia Psychol 2006; 44: 17-27 (in Polish).

8. Luszczynska A, Boehmer S, Knoll N, et al. Emotional suport for men and women with cancer: do patients receive what their partner provide? Int J Behav Med 2007; 3: 156-163.

9. Cohen J. Statistical power analysis for the behavioral sciences. 2nd ed. Hillsdale: L. Erlbaum Associates; 1988.

10. Wojtyna E, Popiołek K. Character of the relationship with Alzheimer patient and the psychological costs of care. Pol Psychol Bull 2012; 43: 244-252.

11. Manne S, Badr H. Intimacy and relationship processes in couples' psychosocial adaptation to cancer. Cancer 2008; 112: $2541-2555$.

Tables: 3

Figures: 1

References: 11

Received: 22.12.2016

Revised: 03.01.2017

Accepted: 03.01.2017

Address for correspondence:

Ewa Wojtyna, MD, PhD

Instytut Psychologii UŚl

ul. Grażyńskiego 53

40-126 Katowice

Polska

Tel.: +48 32 359-97-39

E-mail: ewa.wojtyna@us.edu.pl 